\title{
Enhancing Students' Performances by Integrating Social Media in Undergraduate Learning
}

\author{
Thanuja Chandani Sandanayake \\ University of Moratuwa, Katubedda, Sri Lanka \\ https://orcid.org/0000-0001-5430-6070
}

\begin{abstract}
Use of social media among youth is growing rapidly around the world. This is more common among the young undergraduates. As a consequence of high usage of social media, ability to support learners via social constructed learning has increased. This study focuses on enhancing undergraduate's academic performance via social media intervention. This was an action research and used mix methods inquiry employed quantitative and qualitative studies. Open face to face interviews, semi structured and structured questionnaires were conducted among $94(n=94)$ undergraduates at the Faculty of Information Technology, University of Moratuwa, Sri Lanka. Findings of the study will incorporate the new insights of learner on social media adaption in academic work in meaningful ways. The results of open-ended face to face interviews, semi structured and structured questionnaire demonstrate multiple contextual relationships exist in adaption of social media in formal academic setup. Furthermore, perceptions of undergraduates on social media intervention illustrate the prominent relationship between peer groups, instructors, and learning content. Results of the study indicate that the learners are reluctant to adapt to the traditional learning setups and communication modes, but they appreciate the use of state of art social media connections in learning. Findings will further offer better and important information for both learners and academics to uplift communication, collaboration, and development of conducive learning environments.
\end{abstract}

Keywords: student evaluations; student performances; social media; undergraduate learning; action research

\section{Introduction}

At present, the use of social media has become a ubiquitous part of everyday life, especially among young students (Gazi et al., 2017; Wilfred, 2017). Such social media platforms create a better environment via handheld devices such as smart phones, tablets or computers. One of the key advantages in many of social media is better communication as it connects students, teachers, parents, friends and 
interested parties (Abella-Garcia et al., 2019; Bal, 2017). This collaborative environment of social media encourages the relevant stake holders for rapid-pace of information sharing while facilitating the students to uplift their creativity, analytical thinking, critical thinking, and effective communication process in a better way (Lim et al., 2014; Rajprasit et al., 2015).

Recent studies on social media integration on learning depict that many teachers and professionals in the education sector incorporate social media into their academic work, (Smith, 2016; Sutherland \& Ho 2017) in both online and offline classes to engage students and provide academic support for their educational development (Wilfred, 2017; Zdravkova, 2016). Social media replaces the traditional tool of learning while enabling to share articles with comment functionality, a livestream of an important event, a survey related to course materials, or a question posed to the broader community, collaborative group sharing and communication (Abdillah, 2017; Parusheva et al., 2018).

Undergraduates face many problems due to numerous reasons. Fook and Sidhu (2015) mentioned that ".... attempts to turn the rhetoric into reality are seen as improvements to the teaching and learning process in higher education to further assist students to address their learning challenges". Students face problems in learning when they need to perceive abilities in performing tasks in English (Rajprasit et al., 2015). Moreover, they face bigger challenges in communication with teachers and institution via learning management systems. Therefore, they hesitate to communicate with teachers for multiple aspects due to poor communication problems. However, use of social media among undergraduates is rapidly increasing. This was proven in research investigations on social media on academic success (Crossman \& Bordia, 2011; Ericson, 2011; Hanson, 2011).

Doran and Anderson (2014) mentioned that the social media technologies fall under the umbrella of emerging web technologies and this is increasingly being adopted in higher education settings. Even though the social media integration in academic setting of undergraduate programmes seems effective and successful, some of the prevailing circumstances become an obstacle in such development. Saeed et al. (2009) mentioned in their studies that although the adoption of social media technologies uplifts the academic settings, a major obstacle remains to be "the limited understanding of students' characteristics and perceptions about technology use" (p. 98). Nevertheless, social media integration affords the students and teachers with multiple opportunities to improve learning methods, thus these networks can be incorporated in learning management systems via plugins which enable sharing and integration. Hence, the student gets benefited from the learning activities, materials, videos, tutorials shared through social media networks and LMS's.

This research examined student evaluations through the integration of social media into blended learning of undergraduate students. Study has proven that social media can be incorporated in academic purposes in meaningful manner. 


\section{Review of Literature}

Social media is an electronic media-based technology which facilitates the sharing of ideas, thoughts, and information while building virtual networks and communities. Use of social media is rapidly growing among young generation around the globe as it impacts their private life and academic activities. Use of social media can be seeing increasing among undergraduates as well. Undergraduate learning is the level of education where a learner completes his or her bachelor's degree. Social media platform is a better technological option for students as it provides useful information to create and connect learning groups with a convenient learning environment (Mahdi, 2019). Some social media activities such as review of information, commenting, information classification, blogging, sharing, tagging, and creation of new information are beneficial to the users in learning. Numerous research studies were performed about negative and positive impact of social media on youth (Mushtaq \& Benraghda, 2018; Smith, 2016; Lim et al., 2014; Miss et al., 2014; Powell et al., 2012).

Researchers have found negative impacts of getting addicted to social media. Hence, this situation has to be analyzed and handled with care. Tamir and Mitchell (2012) found that the users are addicted to social media due to the brain activation and the derived pleasure from usage of social media. Hence, students might not provide adequate attention to academic work. Another serious issue in social media addiction is cyberbullying. Here the user experiences threatening or intimidating messages from another person, hacking of passwords of email accounts, sending malicious viral codes via social media (Wired Safety, 2009). Another drawback in social media adaption is overload of information which disable the users to find credible information for them to use at the time of need (Kapoor et al., 2018). However, there are multiple positive impacts on students' lives in using social media.

Use of Social media for academic activities are increasing among young undergraduates. This can be an effective mechanism to reduce frustration and boredom among the students hence they are able to share and connect with peers (Heffner, 2016). Impact of social media on academic studies were investigated by Helou (2014). According to the findings, the majority of undergraduates in Malaysia agree that the social networking sites have a positive impact on the academic performances. At the same time, Mushtaq (2018) argued that the positive impact of social media on the academic activities are much significant than the negative impacts, as many research participants suggested that social media is an advantageous and a beneficial tool in their learning process.

Lim et al. (2014) have investigated about different usages of social media technologies by undergraduates for their academic purposes. Found that both teachers and students explore and accept the use of social media as a tool to engage with the institution and peers in teaching and learning process successfully. Sutherland and Ho (2017) conducted a study to explore the undergraduates' attitudes towards social media usage, used in learning pedagogy and perception on its impact on graduate employability. 
It was identified that the skills used in social media adaption in professional environment is highly positive. It was identified that social media adaption on higher education pedagogy shows the perceived benefits on exploring and entering the job market (Sutherland \& Ho, 2017). As per the literature review by Chugh and Ruhi (2018) on use of Facebook in academic work, it was argued that Facebook is a better educational instrument for teaching and learning. It was further highlighted that peer interactions and teacher-student interaction is enhance through the use of Facebook. Thus, the convenience of learning and higher engagement has improved student performance. Mahdi (2019) argues that the social media platforms such as YouTube, Google Plus groups, Twitter as well as Facebook can act as platforms to resolve students' problems.

Abella-Garcia et al. (2019) conducted a study on use of Twitter which can enhance perceived learning and promote critical thinking, collaborative learning, and active student roles in undergraduate learning (Abella-Garcia et al., 2019). Research on use of Twitter on academic purposes reveal that majority of senior students communicate via twitter and WhatsApp groups (Kimmons et al., 2017; Abella-Garcia et al., 2019). Also, tweets promote to convey information in short, by avoiding long, complex sentences in fully developed paragraphs which are easy to communicate (Gatenby, 2018)

In adapting social media in academic setting, teachers and instructional designers needs to pass major hurdles due to lack of formal guidance in social media adaption such as lack of confidence, innovative design integration, uncertainty and lack of control (Zdravkova 2016, Collis \& Moonen, 2008). Better models of social media to facilitate academic purposes are in need due to unresolved issues in academic settings. Therefore, teachers and instructional designers must be mindful in choosing the appropriate tool for the task. It was argued that social media integration in undergraduate academic setting must be implemented with a sound pedagogical foundation. Academic institutions can enhance traditional delivery modes via promotion of social media among students in learning $\left(\mathrm{O}^{\prime}\right.$ Brien \& Freund 2018).

\section{Research Methodology}

\section{Research Design}

Study has conducted as an action research. Educational action research is disciplined process of inquiry consists of reflective practice which allows inquiry and discussion. (Miskovic et al., 2012; Holly et al., 2009; Burns, 2007). It is also a popular collaborative activity among researchers who are looking for solutions for the problems experienced in educational context. Further, the action research is used by researchers or practitioners with the requirement of investigating and improving their practice (Hendricks, 2009).

Research was conducted to investigate the learning capabilities through the intervention of technology for a better learning context for IT undergraduates. The study has been conducted with a systematic analysis of designing and development of intervention, conduct of intervention as per the research objectives, collection of data about social media intervention, analyzing data and 
reveal, reflect on the implications of data, and development of alternative solutions based on research data. The research has been conducted at the Faculty of Information Technology for 16 weeks. It has been planned to observe the student behavior in social media integration in the course module titled "EEducation". This course is an elective course of 2.5 credits. Social media used in the study was Facebook and Twitter.

\section{Research Objectives}

This study aimed at finding following objectives: (1) Create social media intervention as a communication and collaborative platform to support course activities in learning.; (2) Promote and encourage students to use social media in academic activities of the course through blended mode.; (3) Investigate the student responses and behavior in use of social media in the course activities.; (4) Improve the quality of learning by incorporating social media in academic work.

\section{Participants}

Level 4 undergraduates who follow B.Sc (Hons.) in Information Technology and B.Sc (Hons) in Information Technology and Management took part in the research. Participants were in the age range between 22-24 years among 53 were female students and 41 were males; overall 94 participants $(n=94)$. There are specific reasons for selecting the said course module for the research study and they are: The course content and the domain is directly connected to Education Technology; The students are studying at the highest level of the degree progamme; The course is offered as an elective course; hence the selected students willingly participated in the case study; Students are much familiar with the technology as they are IT undergraduates.

\section{Research Implementation}

The action research was conducted as a cyclic process and multiple stages were involved. Based on the action research model (Kemmis \& McTaggart 1988), the activities of the study have been aligned. Each phase of the action research model has been explained and illustrated by sub research objectives. The first phase is being illustrated as (i) Identify the learning needs and gap in commination through the formal channels.; (ii) Recognize the social barriers in use of LMS; (iii) Recognize the student's technology competency with the teacher, peers and learning content. Sub objective of phase 2 is; Design and develop a social media intervention as a plug in to the LMS. The third phase is illustrated by sub objective; Identify the student responses and perceptions on the social media intervention. The sub objective of final phase is to identify a suitable method to evaluate the learner performance in future. All the phases consisted of different research activities which aligned with the sub objectives. Figure I, explains the different phases of action research and alignment of activities in each phase. 


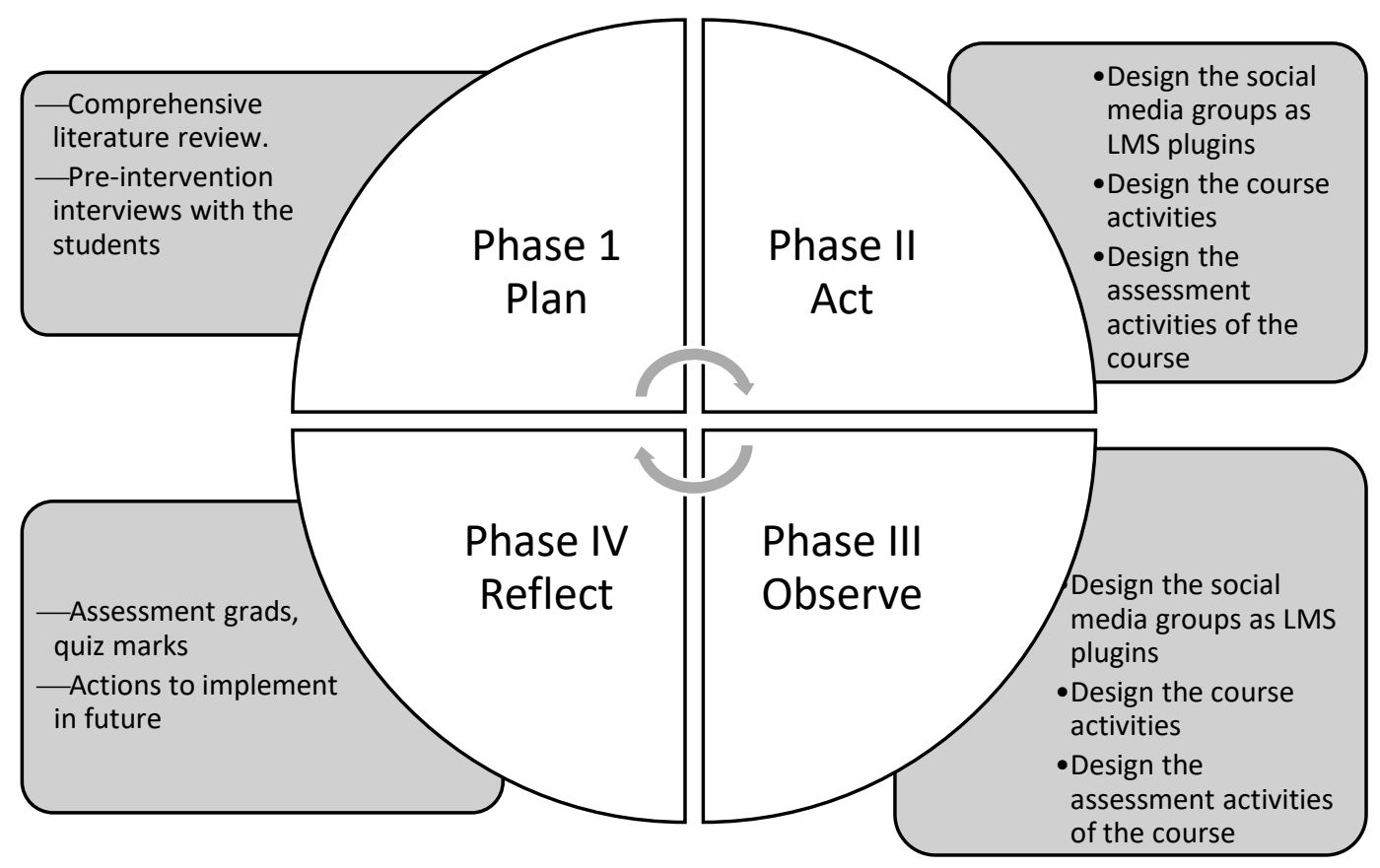

Figure 1: Action research process and activities

\section{Results of Action Research}

\section{Phase I - Plan}

In phase I, two main activities were conducted and the activities are; 1. comprehensive literature review on social media intervention on learning; 2 . Conducted pre-interviews with the students. Fifteen (15) students were interviewed, and results are given in the Table 1.

Table 1. Results of the pre-intervention interviews on social media intervention

\begin{tabular}{ll}
\hline \multicolumn{1}{c}{$\begin{array}{c}\text { Pre-intervention Interview } \\
\text { Questions }\end{array}$} & \\
\hline $\begin{array}{l}\text { I am familiar with the social } \\
\text { media. }\end{array}$ & $-100 \%$ are familiar with social media \\
\hline My level of social media usage & - Excellent $-87 \%$ \\
& $-\quad$ Very Good $-11 \%$ \\
& $-\quad$ Average $-0 \%$ \\
& - Poor -0 \\
\hline & - Not usually use the Moodle as a communication \\
The problems uncounted by & platform \\
me in the current e-learning & - Not very user friendly \\
system in the university are; & - Takes time to locate different activities \\
& - Very bored when using \\
& - Too much content \\
& - Cannot comment on the activities except discussion \\
& - forums \\
& - Leceiving too many Emails \\
& - Cannot share much with the peers except forum \\
\hline
\end{tabular}




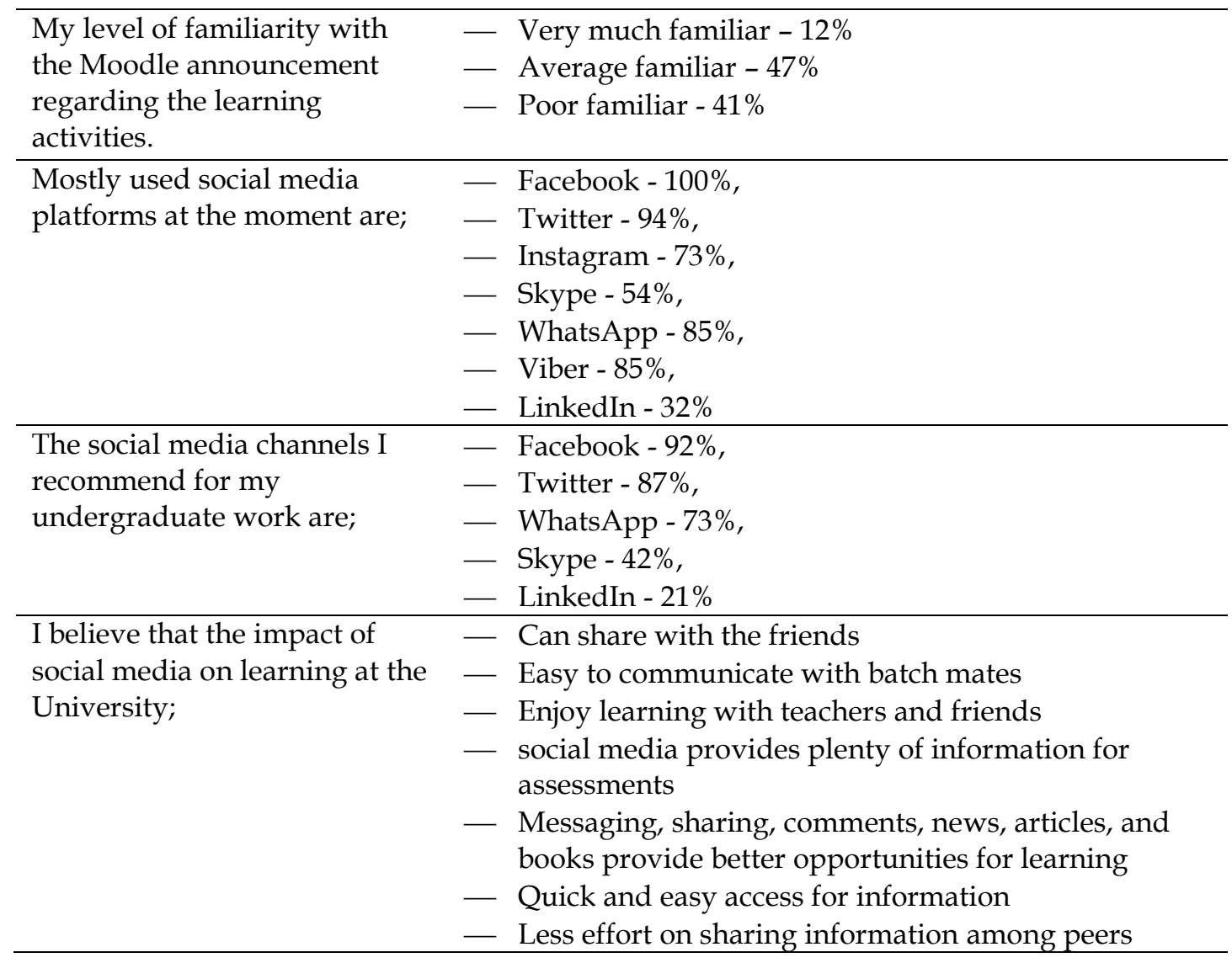

According to the data analysis, almost all the students are familiar with the social media and they are deeply used to it. Majority of the students use Facebook and Twitter as their regular social media platforms; hence they also communicate via WhatsApp groups. It was clearly identified that students show a reservation towards Moodle as a communication and social sharing platform even though it is the official LMS. Majority of students' usage capacity shows a positive engagement as they are much used to social media. Participants commented on many drawbacks identified in the official LMS as it has negatively impacted on learning. According to the interview, one of the participants mentioned that "....we are not quite used to the Moodle since it is not very user friendly. Sometimes we miss the announcements and messages passed by the lecturers. Usually, our batch representative shares the Moodle announcements via Twitter message because that's our usual batch communication mode."

Another response was that the social media communication is much more relaxed and comfortable as they are used to it. The response said "... I don't feel shy and embarrassed in communicating via Facebook and Twitter. But I don't like and do not feel relaxed in Moodle communication because we have to use proper communication ethics and methods when speaking to our instructors and lecturers." Students expressed their dislike on Moodle communication as, "... I don't think Moodle is user friendly like Facebook. But we gain lots of advantages in using Moodle. Sometimes we get many emails from the LMS and feel stressed due to too much of content. We prefer social media platforms since it is a great experience to be with my friends' community around always...". Based on the 
interview results, it can be said that students prefer social media intervention in their learning as it enhances social interaction and communication. Moreover, it is enjoyable, provides quick and easy access and sharing is possible within the community.

\section{Phase II - Design}

Objective of the second phase is to design and develop a social media intervention as a communication platform during learning. Three main activities were conducted in this regard: 1. Designing the intervention course plan, 2 . Development of the concept map, 3. Identifying activities to be implemented in the intervention.

\section{Course Design}

The course is offered in blended mode, (classroom and online mode). Each week is consisted of two-hour face to face lecture session and one-hour tutorial session. Apart from the face-to-face session, the online course has been designed and developed. Moodle has been used as the Learning management system. The online course on Moodle is consisted of many activities that can be conducted by the student such as downloading materials (text, video, audio), quizzes, assessments and discussions.

\section{Social Media Intervention}

Apart from the blended learning modes, social media intervention was also introduced. A Facebook group and a twitter group were created as a closed group in the two social media platforms. The objective of using two social media platforms was to observe the student behavior in each mode. Mainly, the Twitter group was created for the communication purposes of the students and to facilitate the academic activities enhancing the relationship between different groups. Facebook group was mainly used for social interactions; to discuss the issues and build community connections.

\section{Design Assessments}

The course consisted of multiple assessment activities, i.e. individual and group. In the group assessment, the students were supposed to interact with each other in designing and developing the assessment. Social media groups were used in creating the collaborative and conducive learning environment. Assessments were communicated via Moodle and Twitter.

\section{Concept Map}

The concept map of the intervention given in Figure 2 is developed based on four key components: course introduction, course lessons, course materials, assessment criteria and social media intervention. 


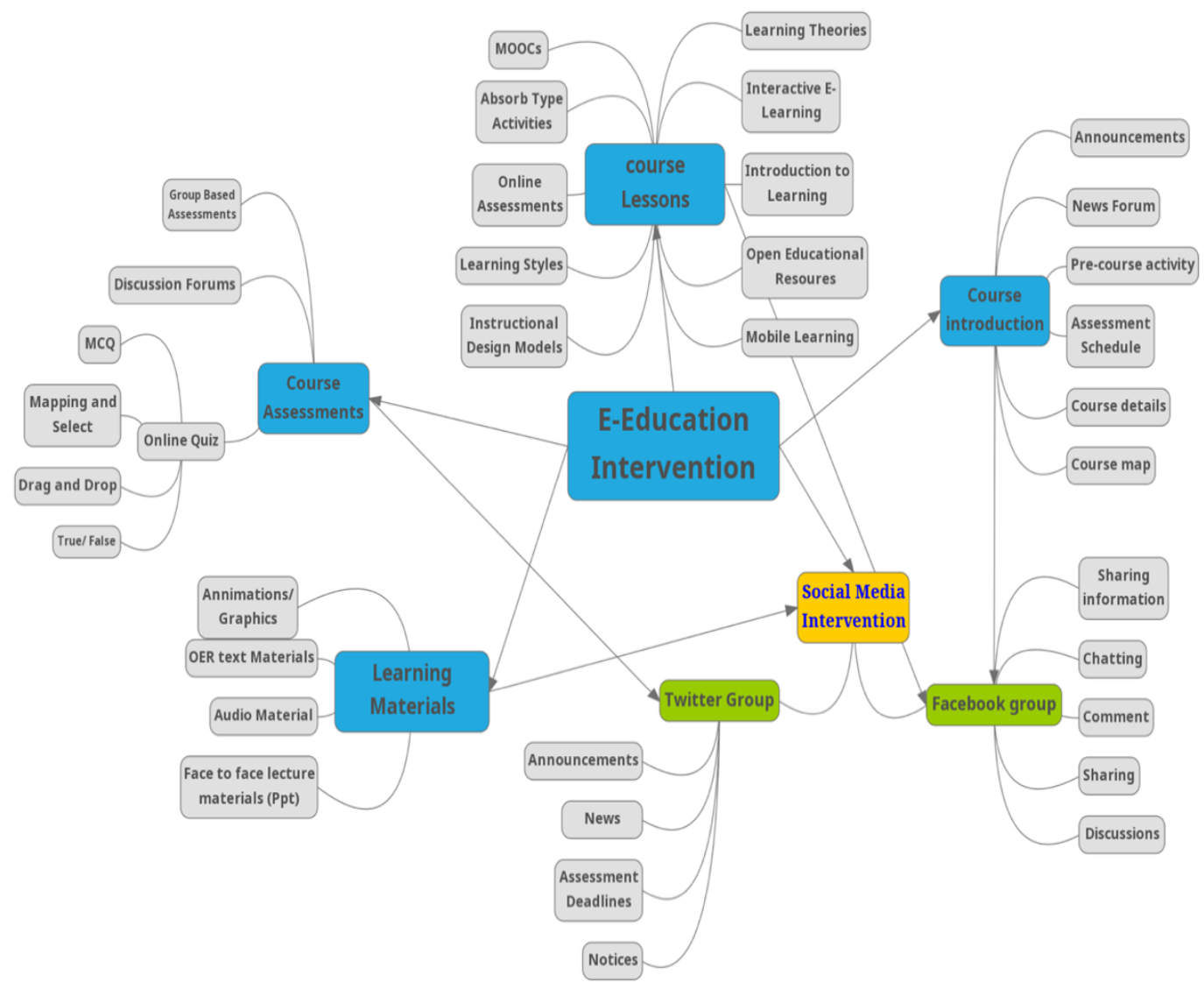

Figure 2: Concept Map of the Intervention Course

\section{Phase III - Observe}

In the phase 3, student responses between 3-4 week and 9-11 week were observed. Table 2 elucidates the demographics of social media usage of all the course participants. According to the results, the whole group of male participants is familiar with the social media, but the females are not very much familiar since nearly $11 \%$ of them are not regular participants.

Table 2: Social Media Usage of Participants

\begin{tabular}{lccc}
\hline & Regular users & Non regular users & Total \\
\cline { 2 - 4 } Participant & $\mathrm{n}(\%)$ & $\mathrm{n}(\%)$ & $\mathrm{N}$ \\
\hline Male & $41(100 \%)$ & 0 & 41 \\
\hline Female & $47(89 \%)$ & $6(11 \%)$ & 53 \\
\hline
\end{tabular}

The next evaluation is about the average time spent in using the social media. Figure 3 depicts that $50 \%$ of the participants use social media for $2-3$ hours per day. Nearly $23 \%$ of students use $1-2$ hours. 


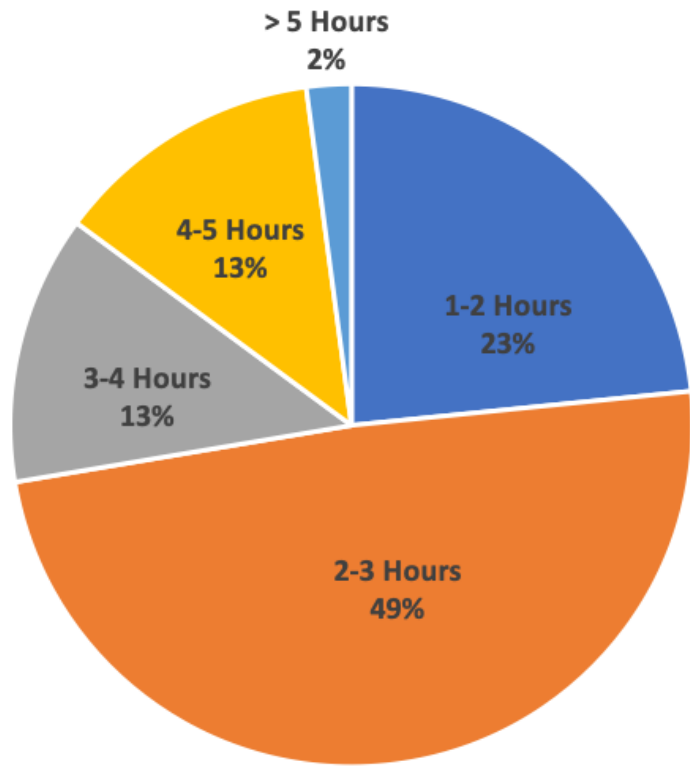

Figure 3: Daily Social media usage

The study has identified the different purposes of social media usage. Highest number of learners use social media for chatting, exchanging information, sharing and commenting. Figure 4 describes students' preferences on different social media usage on a daily basis.

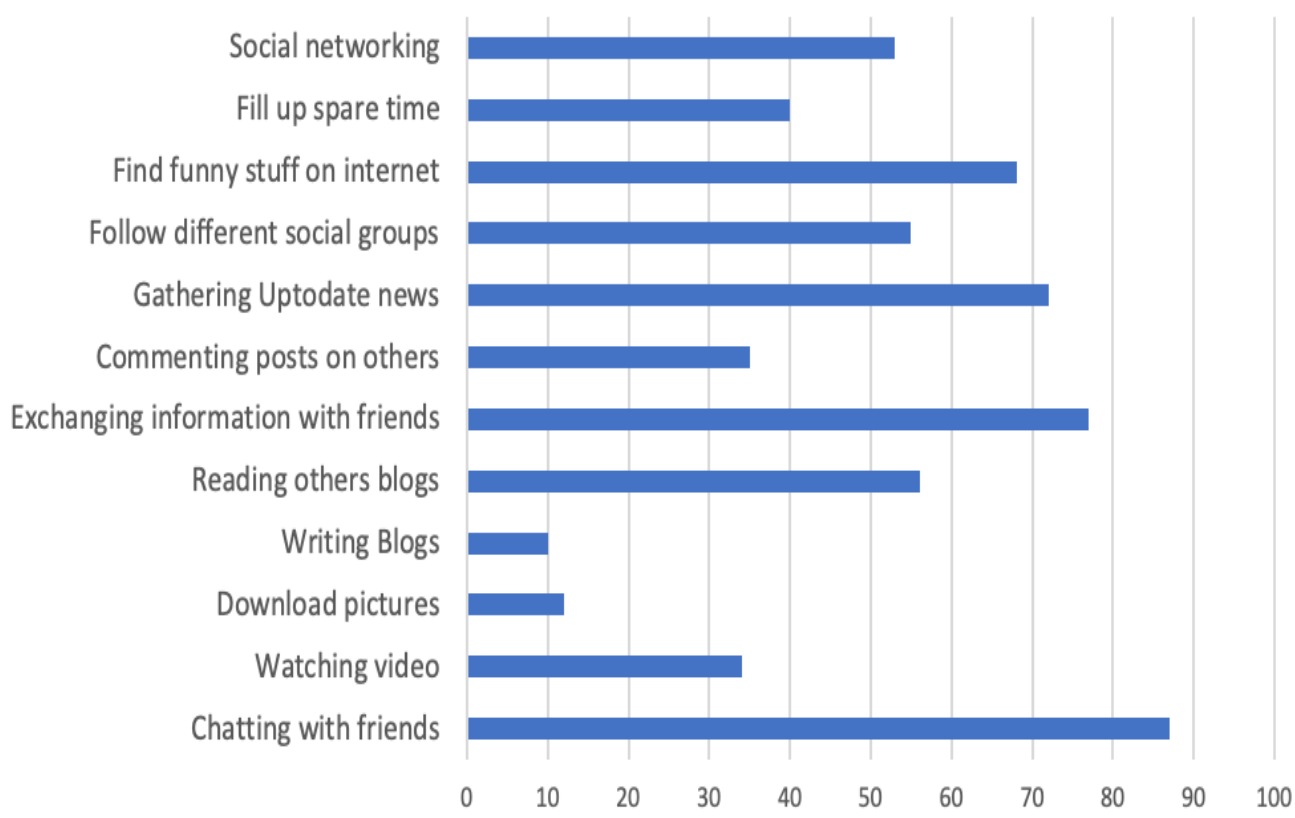

Figure 4: Use of social media for daily purposes

It was important to know about the preferred social media platforms and its usage by the research participants. Figure 4 explains about the popular social media platforms among students. It shows that Facebook, Twitter, WhatsApp and 
Instagram are the most popular among the participants while the learners also use Viber, skype and LinkedIn occasionally.

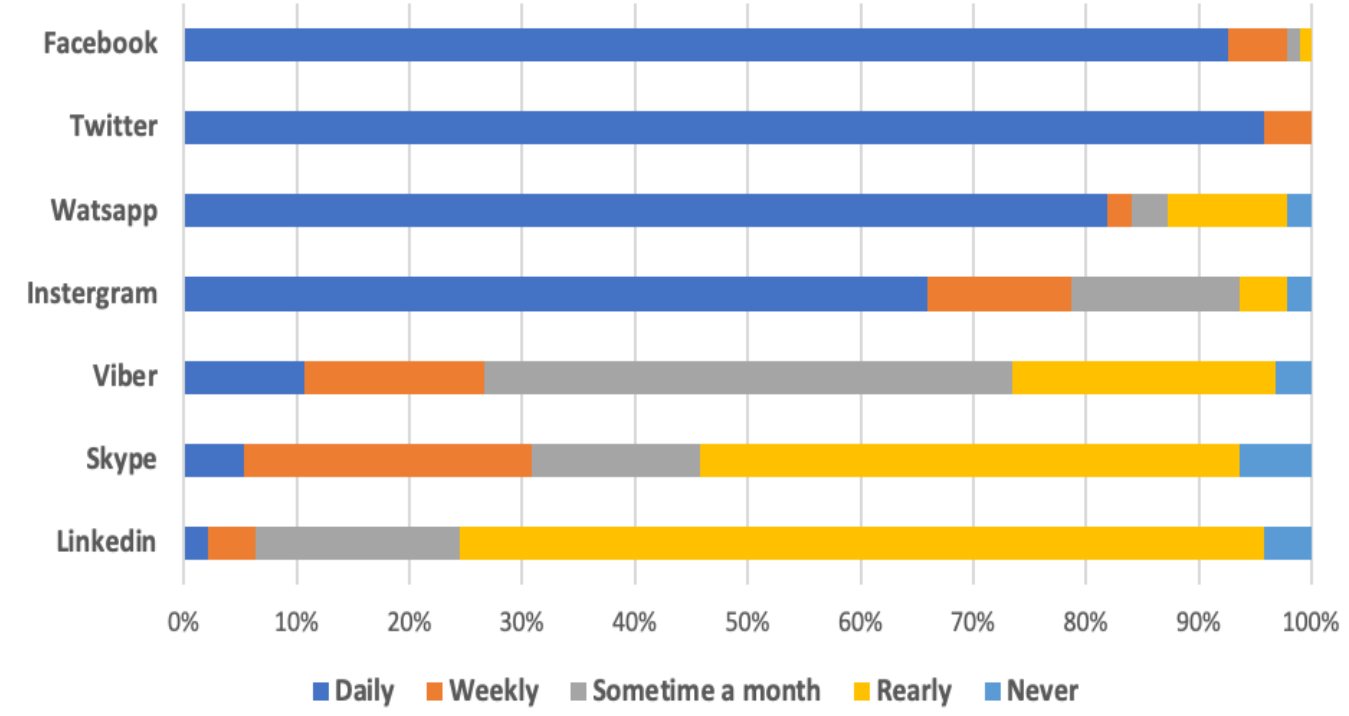

Figure 4: Usage of Social Media Platforms

Student responses regarding the leaning materials, collaborative work in Moodle, assessment activities and social media integration were collected. The questions reflected five main categories and the feedback was given on the scale of 1-5 (Strongly Agree, agree, neither agree nor disagree, disagree and strongly disagree). Responses were received from all the participants $(n=94)$. Table 3 depicts the student responses received from the questionnaire on Social Media Intervention.

Table 3: Student Responses on Social Media Intervention Enabled Moodle Course

\begin{tabular}{|c|c|c|c|c|c|c|c|c|c|c|c|c|c|}
\hline & Question & \multicolumn{2}{|c|}{ 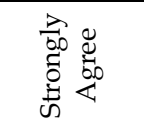 } & \multicolumn{2}{|c|}{ 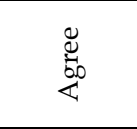 } & \multicolumn{3}{|c|}{ 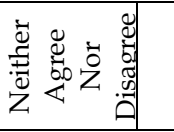 } & & Dू & \multicolumn{2}{|c|}{ 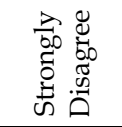 } & ᄃ \\
\hline & \multicolumn{13}{|l|}{ Course Learning Materials } \\
\hline 1 & $\begin{array}{l}\text { Lesson learning materials } \\
\text { shared via social media } \\
\text { help to improve knowledge } \\
\text { and skills }\end{array}$ & 38 & $40 \%$ & 55 & $59 \%$ & 0 & $0 \%$ & & 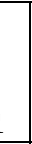 & $1 \%$ & 0 & $0 \%$ & 94 \\
\hline 2 & $\begin{array}{l}\text { Contents of learning } \\
\text { materials are interactively } \\
\text { presented }\end{array}$ & 12 & $13 \%$ & 78 & $83 \%$ & 3 & $3 \%$ & & L & $1 \%$ & 0 & $0 \%$ & 94 \\
\hline 3 & $\begin{array}{l}\text { Learning materials shared } \\
\text { via Facebook are creative } \\
\text { and resourceful }\end{array}$ & 24 & $26 \%$ & 70 & $74 \%$ & 0 & $0 \%$ & & 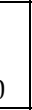 & $0 \%$ & 0 & $0 \%$ & 94 \\
\hline 4 & $\begin{array}{l}\text { Learning materials are } \\
\text { useful to achieve learning } \\
\text { objectives }\end{array}$ & 15 & $16 \%$ & 77 & $82 \%$ & 0 & $0 \%$ & & 2 & $2 \%$ & 0 & $0 \%$ & 94 \\
\hline 5 & $\begin{array}{l}\text { Use of audio and video } \\
\text { lessons shared via social } \\
\text { media are much effective }\end{array}$ & 36 & $38 \%$ & 56 & $60 \%$ & 2 & $2 \%$ & & 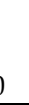 & $0 \%$ & 0 & $0 \%$ & 94 \\
\hline & $\begin{array}{l}\text { Collaborative work in } \\
\text { Moodle }\end{array}$ & & & & & & & & & & & & \\
\hline
\end{tabular}




\begin{tabular}{|c|c|c|c|c|c|c|c|c|c|c|c|c|}
\hline 6 & $\begin{array}{l}\text { Discussion forum } \\
\text { effective and help in } \\
\text { knowledge sharing }\end{array}$ & 3 & $3 \%$ & 18 & $19 \%$ & 33 & $35 \%$ & 27 & $29 \%$ & 13 & $14 \%$ & 94 \\
\hline 7 & $\begin{array}{l}\text { Discussion forums are } \\
\text { timely }\end{array}$ & 1 & $1 \%$ & 23 & $24 \%$ & 24 & $26 \%$ & 32 & $34 \%$ & 14 & $15 \%$ & 94 \\
\hline 8 & $\begin{array}{l}\text { Peers' responses are } \\
\text { motivational and help to } \\
\text { enhance knowledge }\end{array}$ & 12 & $13 \%$ & 32 & $34 \%$ & 37 & $39 \%$ & 10 & $11 \%$ & 3 & $3 \%$ & 94 \\
\hline 9 & $\begin{array}{l}\text { Peer learning discussions } \\
\text { are enjoyable }\end{array}$ & 10 & $11 \%$ & 38 & $40 \%$ & 22 & $23 \%$ & 12 & $13 \%$ & 12 & $13 \%$ & 94 \\
\hline & Assessment Activities & & & & & & & & & & & \\
\hline 10 & $\begin{array}{l}\text { Assessments are } \\
\text { challenging }\end{array}$ & 36 & $38 \%$ & 54 & $57 \%$ & 4 & $4 \%$ & 0 & $0 \%$ & 0 & $0 \%$ & 94 \\
\hline 11 & $\begin{array}{l}\text { Assessment activities } \\
\text { encourage peer learning }\end{array}$ & 18 & $19 \%$ & 71 & $76 \%$ & 2 & $2 \%$ & 2 & $2 \%$ & 1 & $1 \%$ & 94 \\
\hline 12 & $\begin{array}{l}\text { Peer facilitated assessments } \\
\text { done through social media } \\
\text { help in enhancing } \\
\text { knowledge \& skills }\end{array}$ & 34 & $36 \%$ & 57 & $61 \%$ & 2 & $2 \%$ & 1 & $1 \%$ & 0 & $0 \%$ & 94 \\
\hline 13 & $\begin{array}{l}\text { Self-assessment quizzes are } \\
\text { helpful to enhance } \\
\text { knowledge in each lesson }\end{array}$ & 46 & $49 \%$ & 46 & $49 \%$ & 0 & $0 \%$ & 2 & $2 \%$ & 0 & $0 \%$ & 94 \\
\hline 14 & $\begin{array}{l}\text { Assessment activities are } \\
\text { integrated via social media } \\
\text { intervention }\end{array}$ & 21 & $22 \%$ & 67 & $71 \%$ & 4 & $4 \%$ & 2 & $2 \%$ & 0 & $0 \%$ & 94 \\
\hline & Social Media Integration & & & & & & & & & & & \\
\hline 15 & $\begin{array}{l}\text { Social Media platform is } \\
\text { much helpful in } \\
\text { collaboration }\end{array}$ & 44 & $47 \%$ & 49 & $52 \%$ & 1 & $1 \%$ & 0 & $0 \%$ & 0 & $0 \%$ & 94 \\
\hline 16 & $\begin{array}{l}\text { Learning via social media is } \\
\text { very interesting and } \\
\text { encouraging }\end{array}$ & 56 & $60 \%$ & 33 & $35 \%$ & 3 & $3 \%$ & 2 & $2 \%$ & 0 & $0 \%$ & 94 \\
\hline 17 & $\begin{array}{l}\text { Communication via social } \\
\text { media is much more } \\
\text { effective than the usual } \\
\text { methods }\end{array}$ & 58 & $62 \%$ & 36 & $38 \%$ & 0 & $0 \%$ & 0 & $0 \%$ & 0 & $0 \%$ & 94 \\
\hline 18 & $\begin{array}{l}\text { Social media platform does } \\
\text { not distract my academic } \\
\text { performance }\end{array}$ & 36 & $38 \%$ & 55 & $59 \%$ & 1 & $1 \%$ & 2 & $2 \%$ & 0 & $0 \%$ & 94 \\
\hline 19 & $\begin{array}{l}\text { Engage in forums in social } \\
\text { media enhances my skills } \\
\text { and knowledge }\end{array}$ & 33 & $35 \%$ & 59 & $63 \%$ & 2 & $2 \%$ & 0 & $0 \%$ & 0 & $0 \%$ & 94 \\
\hline 20 & $\begin{array}{l}\text { Academic performances are } \\
\text { increased due to the } \\
\text { following of learning } \\
\text { process in social media }\end{array}$ & 22 & $23 \%$ & 69 & $73 \%$ & 2 & $2 \%$ & 1 & $1 \%$ & 0 & $0 \%$ & 94 \\
\hline
\end{tabular}

According to the question category of course learning materials, $40 \%$ have strongly agreed and $59 \%$ have agreed $(=99 \%)$ that the lesson learning materials shared via Facebook are useful in improving knowledge and skills. further, it could be said that these learning materials shared through Facebook are creative and resourceful as $13 \%$ have strongly agreed whereas $83 \%$ have agreed $(=96 \%)$. Student responses on creativity indicated that $24 \%$ have strongly agreed while $74 \%$ have agreed $(=100 \%)$. The study examined the relevance of the learning objectives with the activities. There $16 \%$ of learners were strongly agreed and $60 \%$ of learners were agreed upon. At the same time, 38\% of learners have strongly agreed while $60 \%$ of learners have agreed that audio and video materials shared via Facebook are extremely effective. 
Collaborative learning method enables students to engage in teaching and learning. This is useful for the groups of students in the same batch to work together and solve problems, complete assessments and produce knowledge (Hamalainen \& Vahasantanen, 2011). It was observed that student responses related to the collaborative learning on the Moodle were not in a very positive note. It was observed that student responses on the effectiveness of discussion forums with respect to knowledge sharing, 29\% have disagreed whereas $14 \%$ have strongly agreed on this regard. Moderate responses obtained on the statement stated that 'discussion forums were timely'. At the same time, 27\% strongly agreed and $70 \%$ agreed that the peer responses motivate and help to enhance knowledge in the discussion forums. 13\% have strongly agreed and 34\% have agreed that peer learning via discussions is enjoyable while some have disagreed. This indicates that formal discussion forums are not popular, and leaners have showed passive response towards such forums.

Online assessments are used to cover multiple aspects in learning and connected to achieve common goals and objectives. Here, $38 \%$ of learners strongly agreed and $57 \%$ of learners were agreed that the assessments were challenging. It was observed that $95 \%$ of the students were positive about assessment activities encouraging peer learning via social media. Moreover 36\% have strongly agreed while $61 \%$ have agreed that peer facilitated assessments are useful in improving knowledge and skills. Self-assessment quizzes play an important and integral role in self learning hence $98 \%$ of students have strongly stated that self-assessment quizzes support in boosting knowledge in each lesson. Moreover, $22 \%$ have strongly agreed while $71 \%$ have agreed that the assessment activities are integrated via social media intervention.

One of the key objectives of the study is to observe the student responses on the social media integration. All most all the students (47\% strongly agreed and 52\% agreed) have agreed that Social Media platform is much helpful in collaboration. Study has identified that the social media intervention on learning is interesting and encourages the students to pursue their studies. Hence, $60 \%$ of the students have strongly agreed while $36 \%$ have agreed upon that. Communication during learning is another key element that has been identified and the responses about the efficiency of the social media intervention could be observed as $62 \%$ have strongly agreed whereas $38 \%$ have agreed on that matter. Students are motivated to engage in forums via social media and $35 \%$ of students have strongly agreed and $63 \%$ have agreed that their knowledge and skills have improved. Finally, according to the study, $23 \%$ have strongly agreed while $73 \%$ have agreed on academic performances been increased due to social media intervention.

\section{Phase IV - Reflect}

The fourth phase of action research was to conduct student evaluation after social media integration and to identify the potential actions in conducting future learning activities. The objectives were achieved through student feedback obtained through the intervention and measuring of the student performances. Figure 5 provides an insight into the student performances in four assessment activities. 


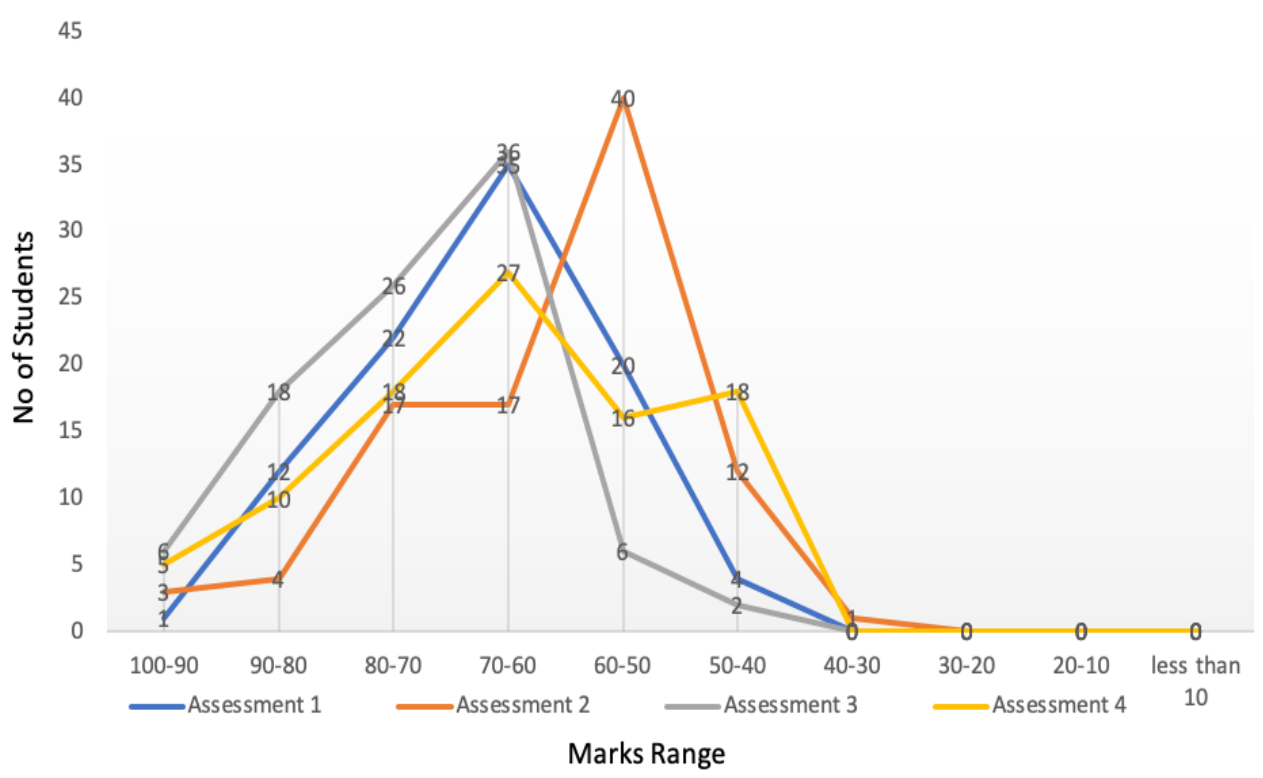

Figure 5: Student Performance of Assessments

According to the evaluation of figure 5, more than $90 \%$ of the students have obtained more than 40 marks which is the lowest grade to be obtained for the eligibility for final examinations. The average mark of assignment 1 is 73, assignment 2 is 61 , assignment 3 is 76 and assignment 4 is 71 . Majority of the students have obtained higher grades for all the assessments and $37 \%, 26 \%, 53 \%$ and $35 \%$ have scored marks between $70-100$.

Face-to-face interviews were conducted with some of the students in order to obtain their views on the social media intervention during the phase 4 . Twelve students were interviewed and has been able to obtain the feedback on the pros and cons. According to the interviews, students positively commented about the enhancement of communication. One student commented that "... it was a wonderful experience I had in this lecture series. I was very weak in asking questions and talking to the lecturers during the lectures. Communication via Facebook and Twitter made me comfortable in communicating with my friends". The comment explains that despite many challenges during academic work, students enjoy collaborative peer learning via social media integration.

"... We are facing many challenges due to heavy workload. We enjoy the collaborative learning via Face book and Moodle. I got support from friends in order to complete assignments, quizzes and other activities." Study results shows a significant relationship between the teachers and peers as they conduct assessment activities and other academic work in the Facebook group. "... Our lecturer and instructor were very helpful in this course. They helped us in finding facts, meeting deadlines and completing assessments successfully by acting as good friends." 
The study observed a variety of ways in which undergraduates perceive social media which facilitate their academic success. Hence, they rely on social media for communication purposes, logistical purposes to create peer groups, to complete assessment activities, to create and maintain relationships between peers and teachers and to share and discuss ideas when learning. These results would benefit both the students and teachers in terms of increasing awareness on enhancing performance via social media intervention addressing communication problems. At the same time academic institutions can pay attention in designing tailor-made blended courses which is perfect fit for student requirements with regard to creating conducive active learning environment. Incorporation of social media into undergraduate learning makes the learners motivated in self-study. Further, the whole learning process has a positive reinforcement toward quality output of learning and teaching. This concept can be further extended into the adult learning especially into the areas of postgraduate learning in university.

\section{Conclusions}

Aim of the study is to identify the impact of social media intervention on academic performance of undergraduates. In conclusion, social media is a very popular and a useful tool for undergraduate students in any academic context as it helps to enhance communication and resolve academic problems giving access to important and relevant information. Students believe that social media groups encourage and motivate them to create social and constructive academic relationships among peers, instructors and content. However, addiction of peer groups towards social media may lead to unnecessary time consumption, tend to share non-academic and irrelevant content or would feel stressed out due to less access to internet facilities.

It was clearly identified that social media applications can be accommodated in official LMS s such as Moodle as a plugin. Negative implications were obtained related to the collaborative activities hosted by Moodle but positive results were obtained with regard to the discussions conducted via social media intervention. Moreover, assessments are integral part of learning which show a significant relationship in social media intervention. Thus, students tend to share information, create ideas, and comment on peer's work, reminding deadlines and work collaboratively using Facebook and Twitter groups. At this point, Twitter acts as informal but regular communication channel and Facebook group acts as sharing, commenting, and collaborative working in the course activities. In the event of social media integration in academic setting, this research suggests accommodating it in a professional learning set up. In the blended mode teaching setup, it is recommended to accommodate the intervention as LMS plugin and address the learning needs carefully before designing learning activities. Further, study proposes teachers to demonstrate active and cooperative participation in social media groups created by the students in order to enhance, motivate and stimulate the interest in learning. 


\section{References}

Abdillah, L. A. (2017). Exploring Students Blended Learning Through Social Media. ComTech (Computer, Mathematics and Engineering Applications), 7(4), 245-254. https://doi.org/10.21512/comtech.v7i4.2495

Abella-Garcia, V., Delgado-Benito, V., Ausin-Villaverde, V., \& Alcala, D.H. (2019). To tweet or not to tweet: Student perceptions of the use of Twitter on an undergraduate degree course.Innovations in Education and Teaching International, 56(4), 402- 411. https:/ / doi.org/10.1080/14703297.2018.1444503

Bal, E., \& Bicen, H. (2017). The purpose of students' social media use and determining their perspectives on education. Procedia Computer Science, 120, 177-181. https://doi.org/10.1016/j.procs.2017.11.226

Burns, A. (2007). Action Research: International Handbook of English Language Teaching. Springer.

Chugh, R., \& Ruhi, U. (2018). Social media in higher education: A literature review of Facebook. Education Information Technology, 23, 605-616. https://doi.org/10.1007/s10639-017-9621-2

Collis, B., \& Moonen, J. (2008). Web 2.0 Tools and Processes in Higher Education: Quality Perspectives. Educational Media International, 45(2), 93-106. https://doi.org/10.1080/09523980802107179

Crossman, J., \& Bordia, S. (2011). Friendship and relationships in virtual and intercultural learning: Internationalizing the business curriculum. Australian Journal of Adult Learning, 51(2), 329-354. https://files.eric.ed.gov/fulltext/EJ951999.pdf

Dron, J., \& Anderson, T. (2014). Teaching crowds: learning and social media. https://doi.org/10.15215/aupress/9781927356807.01

Ericson, B. (2011). The relationship between student use of socially interactive technology and engagement and involvement in the undergraduate experience [Doctoral Dissertation, Boston College, USA]. http://hdl.handle.net/2345/2007

Fook, C. Y., \& Sidhu, G. K. (2015). Investigate the learning challenges faced by students in higher education. Procedia - Social and Behavioral Sciences, 186, 604-612, https://doi.org/10.1016/j.sbspro.2015.04.001

Gatenby, B. M. (2018). Teaching Writing without academic Writing: Transitioning from Aristotle to the Twitter World. International Journal of Language and Linguistics, 5(3). https:// doi.org/10.30845/ijll.v5n3p7

Gazi, M. A., Cetin, M., \& Cak, C. (2017). The research of the level of social media addiction of university students. International Journal of Social Sciences and Education Research, 3(2). https://doi.org/10.24289/ijsser.279705

Hamalainen, R., \& Vahasantanen, K. (2011). Theoretical and pedagogical perspectives on orchestrating creativity and collaborative learning. Educational Research Review, 6, 169-184. https:/ / doi.org/10.1016/j.edurev.2011.08.001

Hanson, K. (2011). Blog enabled peer-to-peer learning. Journal of Dental Hygiene, 85(1), 612. https://jdh.adha.org/content/jdenthyg/85/1/6.full.pdf

Heffner, T. (2016). The effects of social media use in undergraduate students [Masters Dissertations, Rowan University]. http://rdw.rowan.edu/etd/1440

Helou, A. M. (2014). The Influence of Social Networking Sites on Students' Academic Performance in Malaysia. International Journal of Electronic Commerce Studies, 5(2), 247-254. https://doi.org/10.7903/ijecs.1114

Hendricks, C. (2009). Improving Schools through Action Research: A Comprehensive Guide for Educators ( $2^{\text {nd }}$ ed.). Pearson.

Holly, M. L., Arhar, J. M., \& Kasten, W. C. (2009). Action Research for Teachers: Traveling the Yellow Brick Road. Boston. 
Kapoor, K. K., Tamilmani, K., \& Rana, N. P. (2018). Advances in Social Media Research: Past, Present and Future. Information Systems, 20, 531-558. https://doi.org/10.1007/s10796-017-9810-y

Kemmis, S., \& Mc Taggart, R. (1988). The Action Research Planner (3rd ed.). Deakin University Press.

Kimmons, R., Veletsianos, G., \& Woodward, S. (2017). Institutional Uses of Twitter in U.S. Higher Education. Innovative Higher Education, 42, 97-111. https://doi.org/10.1007/s10755-016-9375-6

Lim, J. S. Y., Agostinho, S., Harper, B., \& Chicharo, J. (2014). The engagement of social media technologies by undergraduate informatics students for academic purpose in Malaysia. Journal of Information, Communication and Ethics in Society, 12(3), 177194. https:// doi.org/10.1108/JICES-03-2014-0016

Lim, M. S. C., Vella, A., Sacks-Davis, \& Hellard M. E. (2014). Young people's comfort receiving sexual health information via social media and other sources. International Journal of STD and AIDS, 25(14), 1003-1008. https://doi.org/10.1177/0956462414527264

Mahdi, M. A. (2019). Undergraduate Students' Perceptions toward Social Media Usage and Academic Performance: A Study from Saudi Arabia. International Journal of Emerging Technologies in Learning, 14(3). https:// doi.org/10.3991/ijet.v14i03.9340

Miskovic, M., Efron E. S., \& Ravid, R. (2012). Action Research in Action: From University to School Classrooms. Education Research International, 2012, 1-5. https://doi.org/10.1155/2012/389736

Miss, E. H. N., Obiora, O. C., Odoh, \& Miss, J. N. (2014). The Use of Social Networking Sites among the Undergraduate Students of University of Nigeria, Nsukka. $\begin{array}{llll}\text { Library Philosophy and } & 1195 .\end{array}$ http://digitalcommons.unl.edu/libphilprac/1195

Mushtaq, A, J., \& Benraghda, A. (2018). The Effects of Social Media on the Undergraduate Students' Academic Performances. Library Philosophy and Practice, 1779. https://digitalcommons.unl.edu/libphilprac/1779

O'Brien, M., \& Freund, K. (2018). Lessons learned from introducing social media use in undergraduate economics research. International Journal of Education and Development using Information and Communication Technology, 14(1), 4-16. https://www.learntechlib.org/p/183552/

Parusheva, S., Aleksandrova, Y., \& Hadzhikolev, A. (2018). Use of Social Media in Higher Education Institutions - an Empirical Study Based on Bulgarian Learning Experience. TEM Journal, 7(1), 171-181. https://doi.org/10.18421/TEM71-21

Powell, D. A., Jacob, C. J., \& Chapman, B. J. (2012). Using Blogs and New Media in Academic Practice: Potential Roles in Research, Teaching, Learning, and Extension. Innovative Higher Education, 37, 271-282. https://doi.org/10.1007/s10755-011-9207-7

Rajprasit, K., Pratoomrat, P., \& Wang, T. (2015). Perceptions and Problems of English Language and Communication Abilities: A Final Check on Thai Engineering Undergraduates. Perceptions and Problems of English, 8(3), 111-120. https://doi.org/10.5539/elt.v8n3p111

Saeed, N., Yang, Y., \& Sinnappan, S. (2009). Emerging Web Technologies in Higher Education: A Case of Incorporating Blogs, Podcasts and Social Bookmarks in a Web Programming Course based on Students' Learning Styles and Technology Preferences. Journal of Educational Technology \& Society, 12(4), 98-109. https://www.ds.unipi.gr/et\&s/journals/12_4/9.pdf 
Smith, E. E. (2016). A real double-edged sword: Undergraduate perceptions of social media in their learning. Computer and Education, 103, 44-58. https://doi.org/10.1016/j.compedu.2016.09.009

Sutherland, K., \& Ho, S. (2017). Undergraduate perceptions of social media proficiency and graduate employability: A pilot study. Higher Education. Skills and Work-Based Learning, 7(3), 261-274. https://doi.org/10.1108/HESWBL-02-2017-0018

Tamir, D. I., \& Mitchell, J. P. (2012). Disclosing information about the self is intrinsically rewarding. Proceedings of the National Academy of Sciences, 109(21), 8038-8043. https://doi.org/10.1073/pnas.1202129109

Wilfred, W. F. L. (2017). Effects of social media usage and social media multitasking on the academic performance of university students. Computer in Human Behavior, 68, 286-291. https://doi.org/10.1016/j.chb.2016.11.043

Wired Safety. (2009). Direct attacks. http://www.wiredsafety.com/

Zdravkova, K. (2016). Reinforcing social media-based learning, knowledge acquisition and learning evaluation. Procedia - Social and Behavioral Sciences, 228, 16-23. https://doi.org/10.1016/j.sbspro.2016.07.003 